\title{
Ghrelin As An Ontogenetic Factor And A Gastrointestinal Hormone In The Prenatal And Postnatal Period In Rat
}

\author{
Nadya Penkova ${ }^{1}$, Pepa Atanassova ${ }^{1}$, Elenka Georgieva ${ }^{2}$, Monika Chilikova ${ }^{1}$ \\ ${ }^{\prime}$ Dept. of Anatomy, Histology and Embryology, Medical University, Plovdiv, \\ ${ }^{2}$ Department of Developmental Biology, Faculty of Biology, Plovdiv University "Paisii Hilendarski"
}

\begin{abstract}
Ghrelin is a recently discovered hormone. It was mentioned for the first time by Masayasu Kodzima and associates in 1999. Despite the numerous studies concerning ghrelin, there are still issues to consider. So far there is no definite answer to the question which type enteroendocrine cells produce this hormone. A not less debatable point is the question on the appearance of differentiated ghrelin-producing cells in the prenatal period. So far the earliest occurrence of ghrelin-producing cells in rats is registered in foetal stomach $18^{\text {th }}$ gestation day.

Aim: The aim of our research is to ascertain the occurrence of ghrelin-producing cells in the developing gastrointestinal tract of a rat during the embryonic, foetal and early neonatal period, to study their manifestations and relations to the differentiating elements of the gastro-intestinal wall.

Material and methods: The material for study is of white Wistar rats. We studied rat embryos $8^{\text {th }}-11^{\text {th }}$ gestation day; rat embryos $12^{\text {th }}-15^{\text {th }}$ gestation day; rat fetuses aged $15^{\text {th }}-20^{\text {th }}$ gestation day; fragments of gastrointestinal tract of one-day- old rats. We performed an immunohistochemical study on the ABC method with primary ghrelin antibody and primary antibody of ghrelin receptor GHS.

Results: We found presence of ghrelin-producing cells in the endoblastic epithelium of rat embryos $12^{\text {th }}$ gestation day and fetuses $16^{\text {th }}$ gestation day, as well as in the epithelial lining and glands of the stomach and small intestine of one-day-old rats. A ghrelin receptor is expressed in the same periods in endoblastic and myoblastic cells of the developing digestive tube in embryos and fetuses, as well as in the epithelial lining and glands of the stomach and small intestines of newborn rats.

Conclusion: Ghrelin-producing cells in the gastro-intestinal tract are differentiated as early as the embryonic development of rats. The presence of ghrelin receptors in the endoderm and myoblast of the developing gastrointestinal tube during the embryonic and foetal periods presumes the participation of ghrelin as an inductive signal in the complex processes of cellular proliferation and differentiation. The presence of ghrelin receptors in the mucosa of the stomach and small intestine after birth reveals the ability of ghrelin to participate directly in the regulation of the local processes of the gastro-intestinal wall (secretion, motor and sensory function) without the mediation of the growth hormone.
\end{abstract}

Keywords: gastrointestinal tract, ghrelin, ghrelin receptor GHS-R1, rat embryo

\section{Introduction}

1. Differentiation of the gastro-intestinal tract. The processes of differentiation of the gastro-intestinal tract (GIT) occur in three directions: developing simultaneously in time and space: 1. Phase of proliferation and morphogenesis-organogenesis of the developing GIT; 2. Phase of cellular differentiation, occurrence of different cell types- histogenesis of the developing GIT; 3 . Phase of functional and biochemical maturation [1]. The morphogenetic processes leading to the development of gastrointestinal tract include the formation of the primary intestine, its elongation and sectoral differentiation of the mature organs: esophagus, small and large intestines [2,3,4].

Histogenetical processes in the digestive tube are not performed simultaneously in its entire length. The processes of differentiation take place in a cranioclaudal direction consecutively in the sectors of the future esophagus, stomach, small and large intestines [5,6,7]. In the early stages of embryogenesis, the gastrointestinal tract is a simple endoblastic tube covered by a layer of mesenchyme. Although the process of endoblastic tubulogenesis is not completely studied, it is presumed that it also includes interaction with the mesenchyme which surrounds it [8]. In mice this process ends on $9^{\text {th }}$ gestation day $[9,10]$. The endoderm is differentiated and exhibits all epithelial structures - covering epithelium, glands. Along the length of the anterior-posterior axis of the digestive tube, the endodermal luminal epithelium acquires regional specialization. For example, in the sector of the future stomach, the endoderm is differentiated into single-layered tubular secretory epithelium. In the developing small intestine the covering epithelium develops microvilli necessary for nutrient resorption [11]. Durig 14th gestation day, in rats Manoury et al. establish the presence of immature intestinal epithelial cells which form stratified layer of non polarized epithelial cells. After $18^{\text {th }}$ day gestation, alongside with the 
polarization of epithelial cells, the authors observe apical expression of villin which packs the actin microfilaments into tufts on the axis of microvilli formation [12.13].

Epithelial reorganization, villous morphogenesis, formation of crypts and smooth-muscle layers of the GIT wall is carried out through a complex intercellular signalization between the differentiating endoderm and mesenchyme. The differentiating endoderm releases a number of signaling cells which influence the underlying mesenchyme and smooth muscle cells are differentiated in it. The signal pathways of the endodermal mesenchymal interactions are conservative glycoprotein families with a long evolutionary history. These are growth factors which carry out cascade transductions between embryonic cells. Numerous signal pathways of this interaction are familiar: BMP, Hedgehog (Hh), Sonic hedgehog (Shh), PDGF, TGF- $\beta$, Wnt, TCP, Notch etc. Bidirectional intercellular interactions of the endoderm and mesenchyme of the developing digestive tube are carried out through these molecular mechanisms $[14,15,16,17,18]$.

Abnormal endodermal- mesenchymal interaction with impaired recanalisation and permanent obstruction of the lumen of the small intestine lead to congenital atresia of the small intestine, impaired vascularization of the small intestine wall and the formation of duodenal, jejunal and iliac duplicatures [19,20]. Migration of Paneth cells in the villi epithelium or transformation of the intestinal epithelium into epithelium of gastric phenotype is observed [21,22,23].

Signal pathways of the endodermal- mesenchymal interactions are carried out through growth factors which have non-specific general biological action. On the one hand, the presence of differentiated enteroendocrine cells in the developing gastrointestinal tract with the presence of a secretory product in the cytoplasm and the established processes of secretion and, on the other hand, the proof for receptors for these hormones in the other endodermal or mesenchymal cells would imply that the enteroendocine cells play an important inductive role in the differentiation of the digestive tube.

Bearing in mind the intensive processes of cellular proliferation and differentiation in the early embryonic period, it is significant to know whether there is natural production of ghrelin by the developing embryo or whether it enters the embryo through the mother's blood. This would clarify the role of ghrelin during the embryonic development as well as in the processes of maturation and in the programming of important pathways for exchange, the mechanisms of energy balance, adipogenesis. The discovery of ghrelin receptors in embryonic and foetal tissues would confirm the direct participation of ghrelin in their maturation, in organogenesis and body weight control in the prenatal period.

2. Ghrelin and ghrelin receptor. Ghrelin is an oligopeptide of 28 amino acid residues isolated for the first time from rat stomach. It was first identified by Masayasu Kodzima et al. in 1999 [24]. They ascertained that serum levels of ghrelin in slim rats are higher than those of fat ones [24,25]. The basic functions of ghrelin are two. Ghrelin participates in the formation of severe feeling of hunger through its connection with specific receptors in the nuclei of the diencephalon. It releases growth hormone secretion through receptors in the adenohypophysis,. The root of the term 'ghre' derives from 'grow'. Metabolic effects of ghrelin are due to its function to be a ligand for the growth hormone secretory receptor in the adenohypophysis. Plasma levels of ghrelin increase on an empty stomach and after feeding they return to their normal levels [26,27,28]. Factors which influence ghrelin secretion are blood sugar levels, resp. insulin, the composition of the ingested nutrients. High fructose levels and low protein food content increase this secretion. Diet high in lipids decreases plasma levels of ghrelin [29].

Ghrelin exists in two forms- acylated and nonacylated ghrelin. $70 \%$ of serum ghrelin is in a nonacylated form. Most authors consider acylated ghrelin hormone active. Acylated ghrelin, related to GHSRtype 1a plays a major role in the regulation of somatotropic function [24,30]. Some metabolic effects of ghrelin, however, are irrespective of its acylation. This supports the hypothesis for the existence of subtype receptors for ghrelin different from GHS-R1A [31].

The earliest appearance of ghrelin producing cells in the prenatal period of rat development is registered in the rat's stomach on $18^{\text {th }}$ gestation day $[32,33,34]$. Till the end of the fetal period these cells are single [32]. Not until the second, third week of postnatal development do the count of ghrelin producing cells in the rat stomach increase [35].

Ghrelin receptor GHS-R1 is a G-coupled peptide cloned for the first time in 1996 from adenohypophysis and hypothalamus [36]. Its binding with ligands leads to the release of growth hormone secretion. In 1999, after its discovery, ghrelin was identified as an endogenous ligand congenial to this receptor [37]. Two isoforms of the ghrelin receptor have been synthesized: GHS-R1A and GHS-R1B. Through the use of Bioluminescence Resonance Energy Transfer (BRET), heterodimers of GHS-R1A and GHS-R1B are shown during a process of oligomerisation in the endoplasmic reticulum of isolated subcellular fractions [38]. GHS$\mathrm{R} 1 \mathrm{~A}$ is a mature polypeptide of 366 amino acid sequences and 5 transmembrane domains [39]. 
In the last years ghrelin receptors are sought outside the central nervous system. This would mean that ghrelin functions not only through the release of the growth hormone, but it has a direct hormonal effect on target cells in the peripheral tissues.

In GIT ghrelin receptors have been found in rat and guinea pig. While studying ghrelin and its receptor in rats $\mathrm{Fu}$ et al., (2011) [40] establish GHS-RmRNA expression in the rat stomach fundus. Kitazawa et al., (2011) [41] identify ghrelin receptor GHS-R1A in vegetative afferent nerve fibres and smooth muscle cells from stomach, small and large intestine of a guinea pig. In isolated sections of these organs ghrelin causes marked contractions of the muscles of the stomach and large intestine and slighter ones in the sections of the small intestine. This data gives the authors the grounds to assume ghrelin participation in the regulation of the gastrointestinal peristalsis and its disorders [40,41].

Aim: The aim of the present study is to establish the occurence of ghrelin producing cells in the developing gastrointestinal tract of a rat during the embryonic, fetal and early neonatal period and to study their occurrence and interactions with the differentiating elements of the gastrointestinal wall.

\section{Material and methods}

The material of study is white Wistar rats. We studied rat embryos, fetuses and GIT fragments of oneday-old rats. It is obtained by 24 male white rats inseminated through contact with male specimen fixed in time. The material is distributed in four age groups: $1^{\text {st }}$ group of $8^{\text {th }}-11^{\text {th }}$-day-old rat embryos; $2^{\text {nd }}$ - group of $12-15^{\text {th }}$ day-old rat embyos; $3^{\text {rd }}$ group of $16^{\text {th }}-20^{\text {th }}$ gestation day old rat fetuses; $4^{\text {th }}$ group of one-day old newborn rats (Table №1)

Table № 1. Material from experimental animals. Age groups.

\begin{tabular}{|c|c|c|c|}
\hline Group & Gestational day & Number & Size of the embryo \\
\hline I & $8-11$ & 8 embryos & $4 \mathrm{~mm}$ \\
\hline II & $12-15$ & 22 embryos & $10 \mathrm{~mm}$ \\
\hline III & $16-20$ & 20 fetuses & $15 \mathrm{~mm}$ \\
\hline IV & $21-22$ & 10 newborn & GIT fragments \\
\hline
\end{tabular}

We performed an immunohistochemical study of ghrelin and ghrelin receptor GHSR-1. Immunohistochemical reactions were performed according to the $\mathrm{ABC}$ method through rabbit $\mathrm{ABC}$ Staining System (Santa Cruz Biotechnology, USA) with the respective primary antibody (Table № 2.).

\begin{tabular}{|c|l|c|c|c|}
\hline Antibody & \multicolumn{1}{|c|}{ Catalogue number } & $\begin{array}{c}\text { Dilution } \\
\text { in PBS }\end{array}$ & $\begin{array}{c}\text { Localisation of } \\
\text { expression }\end{array}$ & Granule colour \\
\hline Ghrelin & $\begin{array}{l}\text { goat polyclonal } \\
\text { ghrelinantibody (C-18): sc- } \\
10368 \text { - Santa Cruz } \\
\text { Biotechnology USA }\end{array}$ & $1: 100$ & cytoplasmic & Black granules \\
\hline $\begin{array}{l}\text { Ghrelin } \\
\text { receptor } \\
\text { GHSR-1 }\end{array}$ & $\begin{array}{l}\text { goat polyclonal antibody } \\
\text { GHSR-1: sc-10351 - Santa } \\
\text { Cruz Biotechnology USA }\end{array}$ & $1: 100$ & cytoplasmic & $\begin{array}{c}\text { Fine brown } \\
\text { granules }\end{array}$ \\
\hline
\end{tabular}

Table № 2. List of the primary antibodies used in the IHC test.

The material is fixed in a Buen solution for 24 hours and contains paraffin. Paraffin sections with a thickness of $5 \mu$ mce deparaffinize and incubate for 30min. in a $2 \% \mathrm{H} 2 \mathrm{O} 2$ methanol for inactivation of endogenous peroxidase. The primary ghrelin antibody (goat polyclonal ghrelin antibody: sc-10368 - Santa Cruz Biotechnology USA) is diluted in PBS in 1:100 ratio. The primary ghrelin antibody for ghrelin receptor GHSR1 (goat polyclonal antibody GHSR-1: sc-10351 - Santa Cruz Biotechnology USA), is diluted in PBS in 1:100 ratio. We used a semi-quantitative evaluation method for the obtained results. Positive reaction for ghrelin is reported in the presence of black granules in the secretory granules in cells. Positive reaction for ghrelin receptor GHS-R1 is reported in the presence of fine brown granulation in the cell cytoplasm. The specificity of immunohistochemical reactions for each studied antigen is confirmed by negative controls in which the specific antibodies are substituted with a buffer (PBS) or normal non-immune serum. In them there is a complete lack of a product of the respective reaction. Observation and photo documentation of microscopic preparations are performed with digital photo microscopic camera of a light microscope "Olympus BX51".

\section{Rat Embryos}

\section{Results}

Hematoxylin and eosin staining. The earliest structure belonging to the gastrointestinal tract is studied in rat embyos from $8^{\text {th }}-11^{\text {th }}$ gestation day. In them we observed a digestive tube built by conical-prismatic 
endodermal cells. Cell nuclei are arranged in 2-3 rows. The cells are situated on a clearly visible basal lamina. The underlying layer of mesenchyme is light, spacious, well-defined (Fig.1). In rat embryos $12^{\text {th }}-15^{\text {th }}$ gestation day, GIT is already a tube-like structure in which the processes of cellular proliferation and differentiation have lead to the formation of various tissue layers. The digestive tube on this stage is lined with multilayered endodermal epithelium located on a clearly visible basal lamina. Areas of myoblast cells are observed in the surrounding mesenchyme. They are with elongated shape. Tufts with longitudinal and others with circular direction are differentiated. The digestive tube is covered by one layer of cuboidal coelomic cells. In this manner the splanchnopleura appears to be a source of the future serous membrane. Thus formed, the digestive tube is situated in the coelomic cavity of the rat embryo (Fig. 2.).

Fig. 1. Cross section of endodermal tube covered by a layer of mesenchyme. Rat embryos $8^{\text {th }}$ gestation day. Paraffine preparation. HE stain. x 40 .

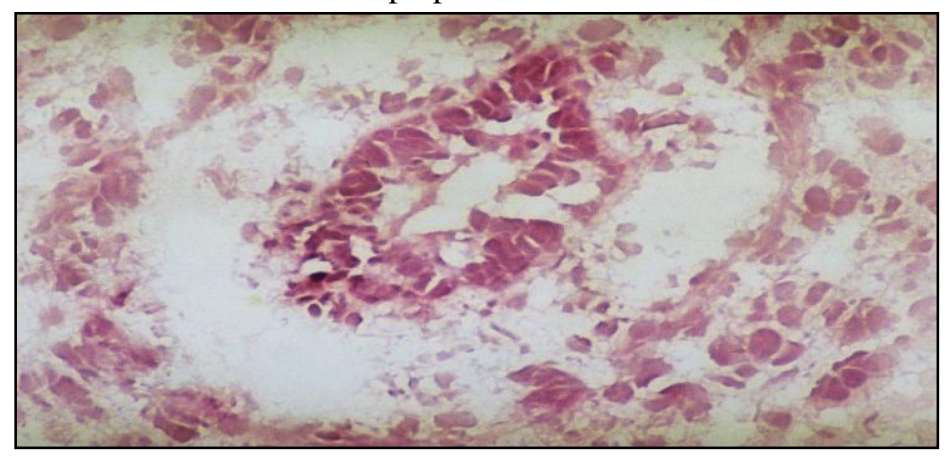

Fig. 2. Digestive tube of rat embryos $12^{\text {th }}$ gestation day. Paraffin preparation. HE stain. $x 20$.

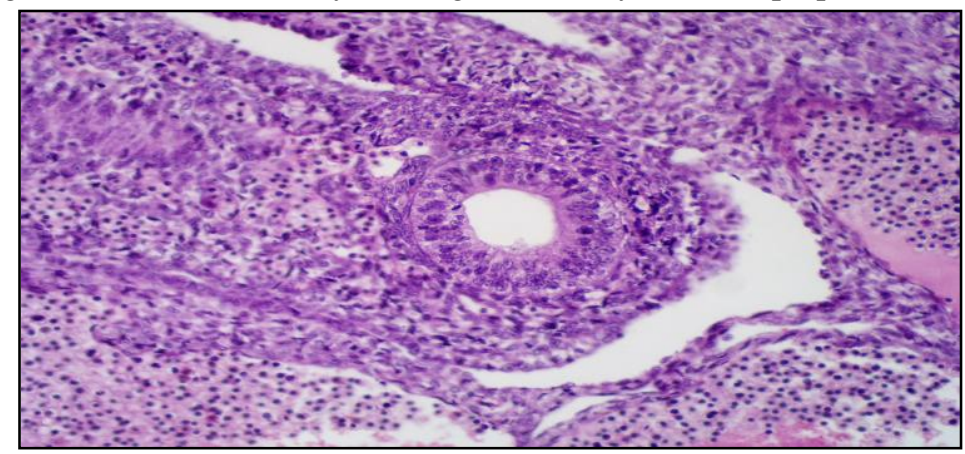

Immunohistochemical reaction for ghrelin and ghrelin receptor GHS-R1. In the developing GIT of rat embryos $12^{\text {th }}-15^{\text {th }}$ gestation day we establish a positive immunohistochemical occurrence of ghrelin. For the first time the reaction for ghrelin and its receptor GHS-R1occurs as positive on $12^{\text {th }}$ gestation day. Individual ghrelinpositive cells are localized among the endoderm of the digestive tube (Fig. 3). Expression of ghrelin receptor GHS-R is found in individual endodermal cells from the covering epithelium as well as in myoblast cells from the surrounding mesenchyme (Fig. 4).

Fig. 3. Digestive tube of rat embryos on $12^{\text {th }}$ gestational day. Positive IHC reaction for ghrelin. Paraffin preparation. $\mathrm{x} 20$

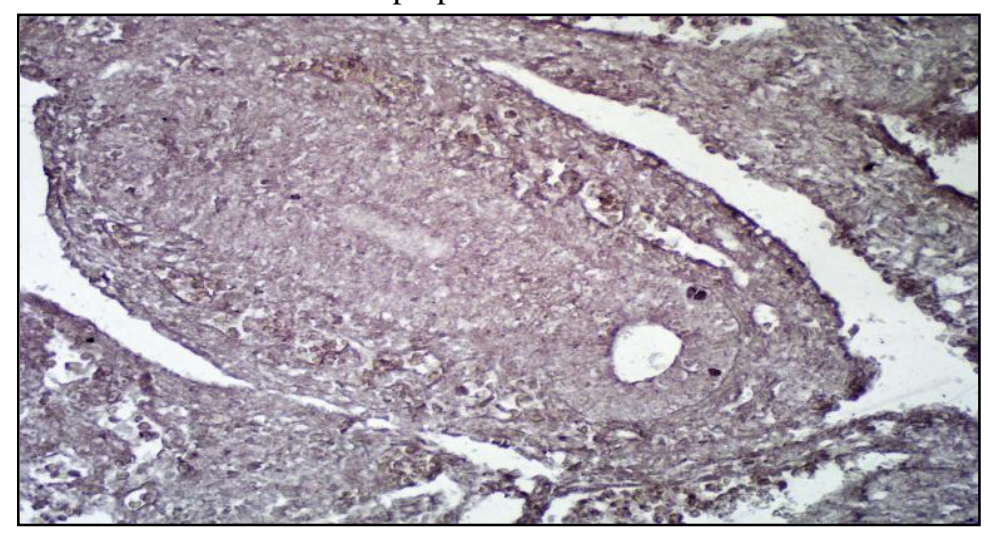




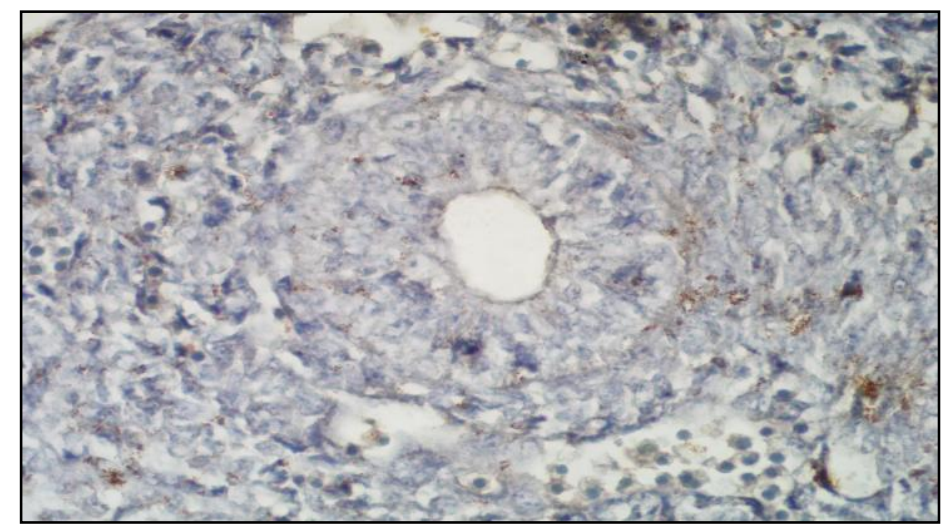

Fig. 4. Digestive tube of rat embryos $12^{\text {th }}$ gestation day. Positive expression for ghrelin receptor GHS-R1 in endodermal and myoblast cells IHC. Paraffin preparation x 40 .

\section{Rat Fetuses $16^{\mathrm{TH}}-20^{\mathrm{TH}}$ Gestational Day}

Hematoxilin-eosin staining. In rat fetuses $16^{\text {th }}-20^{\text {th }}$ gestation day sector differentiation of the digestive tube is present. An esophagus, a stomach, small and large intestine are present. In fetuses form $16^{\text {th }}$ gestation week the parts of the small intestine are located outside the abdominal cavity but at the end of the fetal period they are finally located in the peritoneal cavity. Serous formations, which attach the developing organs to the abdominal wall, are observed. Rat fetal stomach still lacks separate parts- cardia, corpus, pylorus. A thick layer of multilayered endoblast epithelium lines the gastric wall. Parietal areas are formed among the epithelial cells. Thus, the direction of the future gastric glands is marked. A well vascularized mesenchyme is located in the endoblast. The future muscle sheath is presented by thin layers of smooth muscle cells which at this stage form two layers with different function. The small intestine wall in rat fetuses $16^{\text {th }}$ gestation day is immature, with different characteristic in the direction of the organ. In some of the transverse sections folds of covering epithelium can be observed. They are short and wide covered by cuboid endoblast cells in one or more rows are filled with a large amount of mesenchyme. Under the folds a thick mesenchymal layer, rich in capillaries, is found. A thin layer of elongated smooth muscle cells, arranged in a circular direction in two or three rows, is located in its periphery. In other sections there are already formed villi. Rudiments of crypts are observed at the same time (Fig. 5).

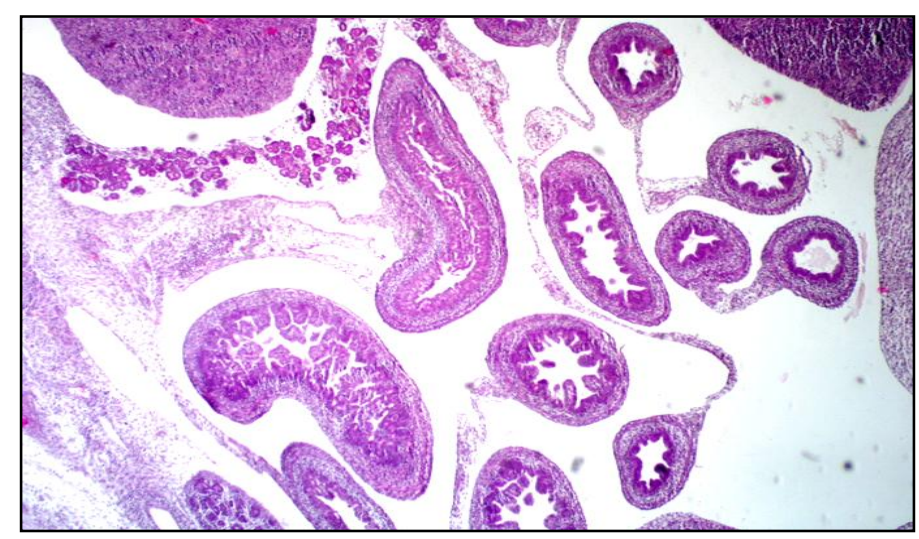

Fig. 5. Sagittal section of rat fetus $16^{\text {th }}$ gestational day. Intraperitoneally located parts of the digestive tube. Paraffin preparation. HE stain. $\mathrm{x} 4$.

Immunohistochemical reaction for ghrelin and ghrelin receptor GHS-R1. Immunohistochemical reaction for ghrelin is positive in the stomach and small intestine of rat fetuses $16^{\text {th }}-20^{\text {th }}$ gestation day. Black granules are observed in a small number of stomach wall endoderm cells. In the stomach ghrelin is expressed in the cells of the deeper layers of endoderm, as well as in the more superficial cells (Fig. 6). The reaction is positive also in the single cells from the small intestine epithelium (Fig. 7). IHC reaction for ghrelin receptor GHS-R1 is positive in the wall of the developing stomach of rat fetuses $16^{\text {th }}-20^{\text {th }}$ gestation day. There is presence of fine brown granulation in groups of endodermic cells (Fig. 8). Expression of ghrelin receptor GHS$\mathrm{R} 1$ is also found in a thin layer of smooth muscle cells in the periphery of the gastric wall (Fig. 9). 


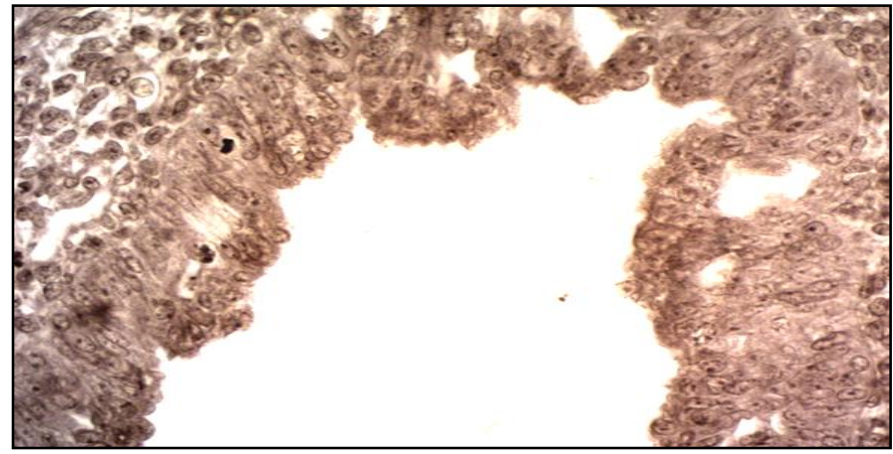

Fig. 6. Rat fetus stomach $16^{\text {th }}$ gestation day. Single ghrelin positive cells in the multilayered endodermal epithelium. IHC. Paraffin preparation. $x 40$.

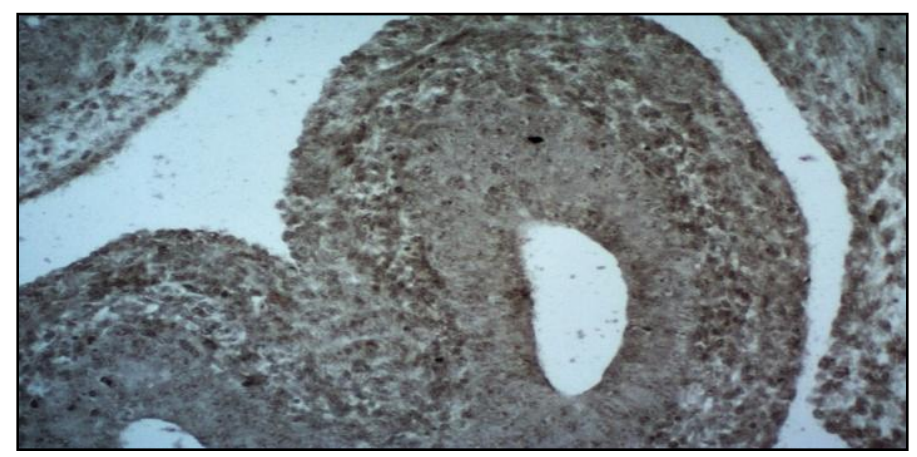

Fig. 7. Rat fetus small intestine $16^{\text {th }}$ gestation day. Ghrelin positive cell in the multilayered endodermal epithelium. IHC. Paraffin preparation. x 20.

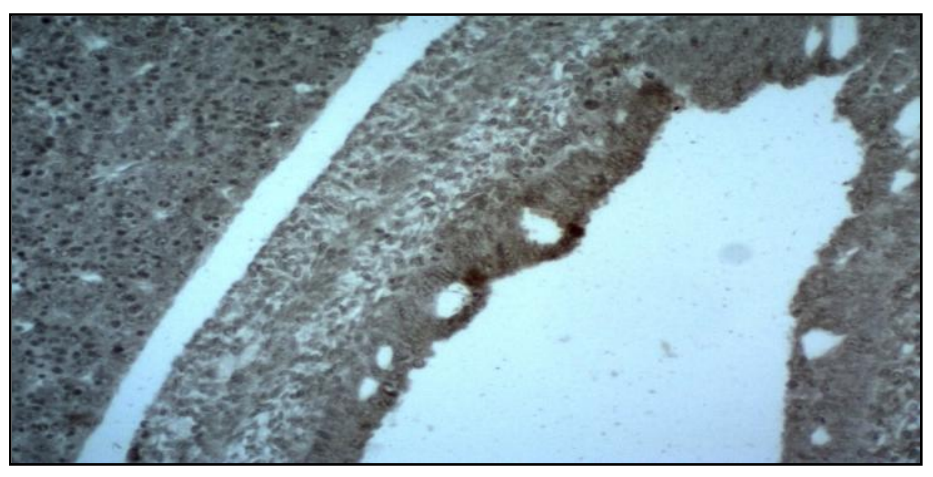

Fig. 8. Rat fetus stomach $16^{\text {th }}$ gestation day. Positive reaction for ghrelin receptor GHS-R1. IHC. Parafin preparation. x 20.

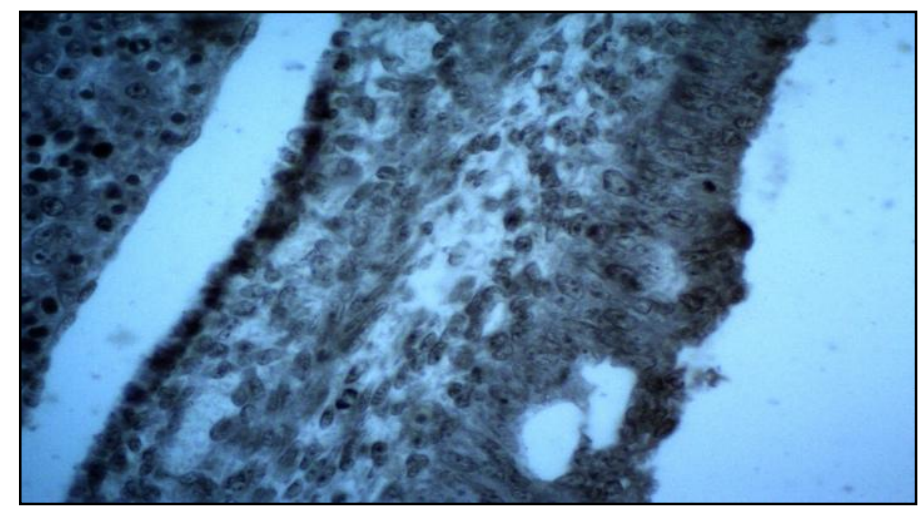

Fig. 9. Rat fetus stomach $16^{\text {th }}$ gestation day. Positive reaction for ghrelin receptor GHS-R1 in peripheral smooth muscle layer. IHC. Paraffin preparation. x 40 


\section{Newborn Rats - One- Day- Old Rats (21 ${ }^{\mathrm{ST}}$ Day)}

Hematoxin-eosin staining. In one-day-old rats the morphological characteristics of GIT reveal the typical picture of a tube-like organ. All tissue layers of the mucosa in the gastric wall are well-formed. The covering epithelium is single layered columnar secretory. The glands in its lamella are densely located. Twothree layers of smooth muscle cells limit the underlying loose connective tissue of the submucosa. Dense smooth muscle layers with circular, longitudinal and oblique direction are formed in the muscle sheath. The morphogenetic and morphological processes in the small intestine wall have advanced significantly. A presence of tall, parallel villi located at some distance. They have thinned basal and broadened central part. The cells of the covering epithelium are tall, cylindrical with well-defined striated surface - a sign for presence of welldeveloped microvilli. There are shallow, scanty crypts between the villi. The muscle sheath is built by fusiform smooth muscle cells arranged in dense layers with various course (Fig. 10).

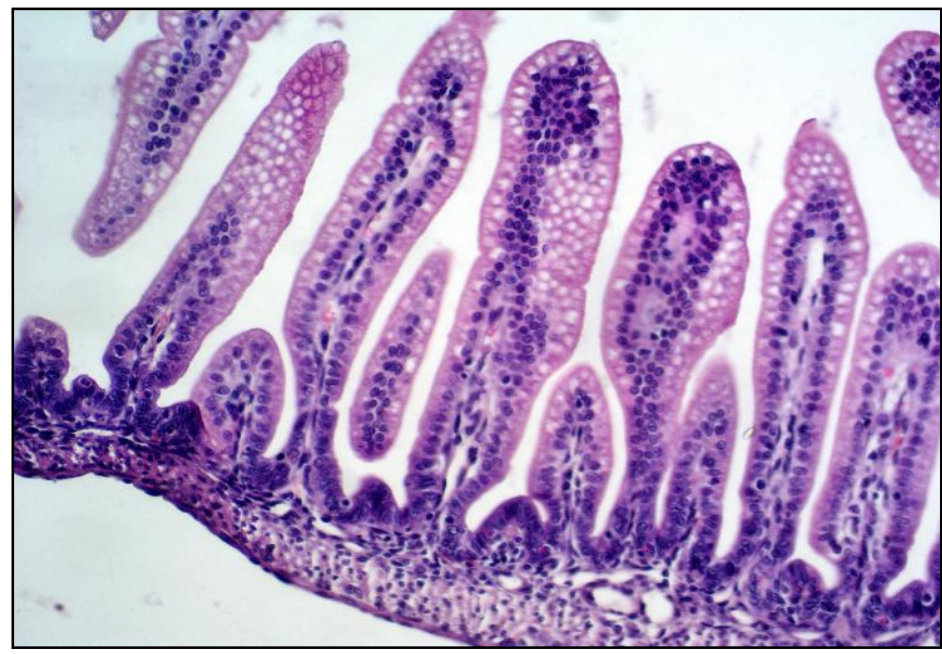

Fig. 10. Small intestine from one-day-old rat. Well-shaped villi, shallow crypts, dense layers of smooth muscle cells. Paraffin preparation HE stain. $\mathrm{x} 20$.

Imunohistochemical reaction for ghrelin and ghrelin receptor GHS-R1. Our imunohistochemical investigations show that in GIT of one-day-old rats there is presence of positive expression of ghrelin in the stomach and small intestine. Ghrelin positive cells are also observed in the gastric mucosa. In the gastric cardia gherlin is expressed in single cells located in the base of cardiac glands. Imunohistochemical reaction is with moderate intensity (Fig. 11). In the gastric fundus a positive reaction of a large number of cells from the bottom of the main glands is established. Ghrelin expression in them is slight to moderate (Fig. 12). Ghrelin positive cells are also present in the corpus of the stomach. There is a large number of ghrelin positive cells with high intensity of IHC reaction. In them the black granules fill densely the whole cytoplasm of the cell (Fig. 13).

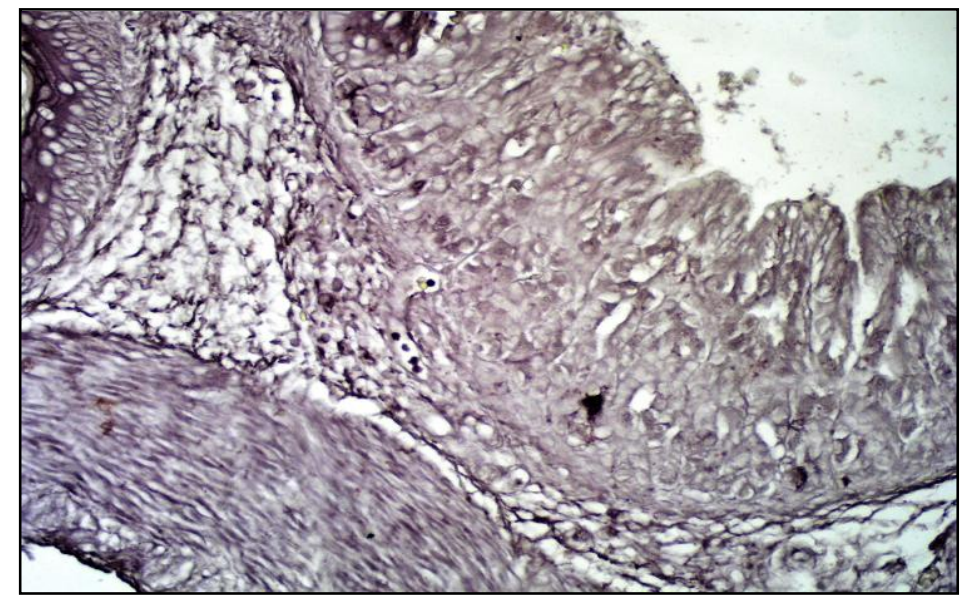

Fig. 11. Stomach of a one-day-old rat-parscardiaca. Positive expression of ghrelin in single cells from the base of cardiac glands. IHC. Paraffin preparation. x 20. 


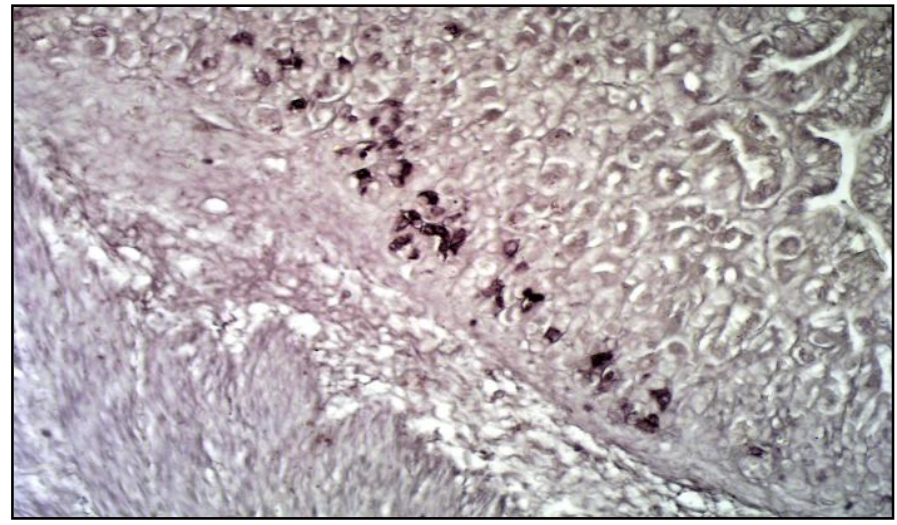

Fig. 12. Stomach of a one-day-old rat- fundus. Positive ghrelin expression in a large number at the base of the chief glands. IHC. Parffin preparation. x 20.

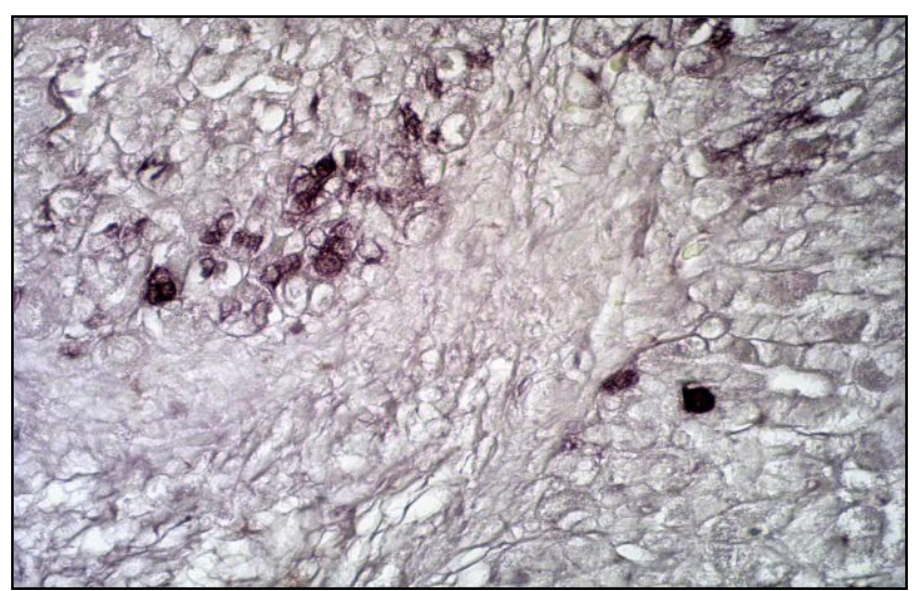

Fig 13. Stomach of a one-day-old rat- corpus. Positive ghrelin expression in a large number of cell at the base of chief glands. A single cell with high intensity of the reaction. IHC. Paraffin preparation. x 20.

In the small intestine of one-day-old rats there is presence of ghrelin-positive cells. They are single. They are found in the covering epithelium of villi. IHC reaction in some of them is highly intensive and in others- with moderate intensity (Fig. 14, 15).

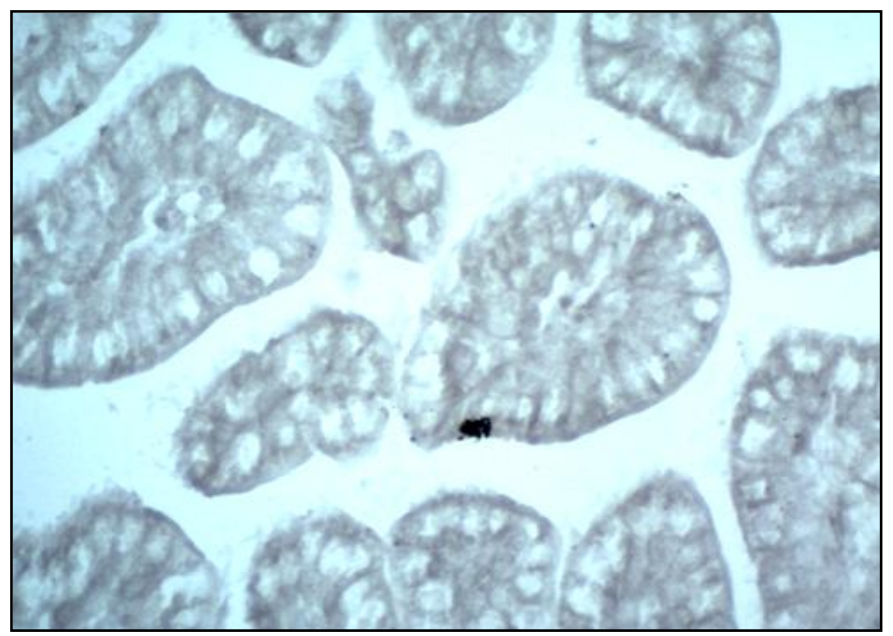

Fig. 14. Small intestine of a one-day-old rat. Cross section of a villus with ghrelin-positive cell in the covering epithelium. IHC. Paraffin preparation. $x 40$. 


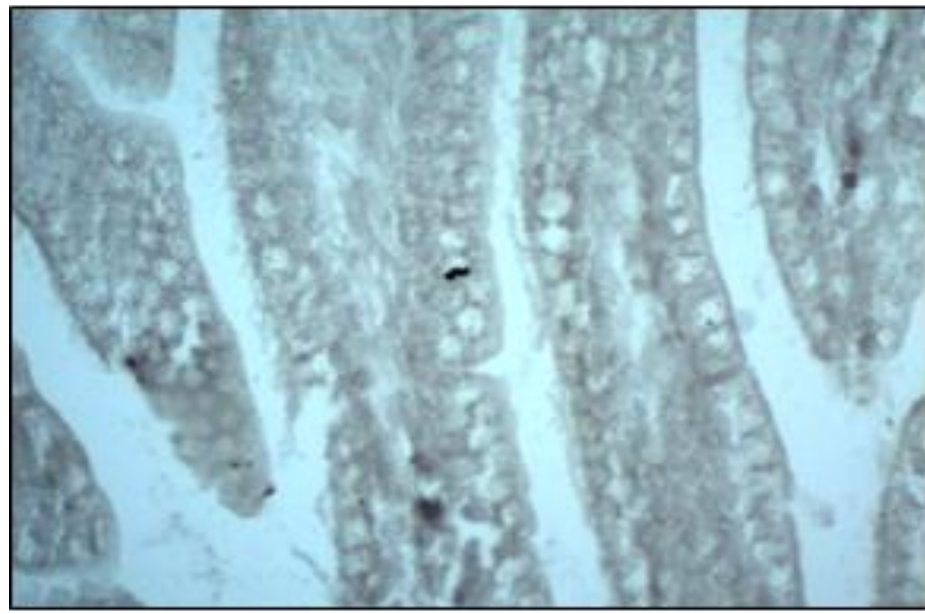

Fig. 15. Small intestine of a one-day old rat. Longitudinal section of a villus with ghrelin-positive cell in the covering epithelium. IHC. Paraffin preparation. x40.

IHC reaction for ghrelin receptor in GIT of one-day-old rats is positive. Ghrelin receptor GHS-R1is expressed in the gastric wall. The reaction is positive in individual cells of the covering epithelium (Fig. 16) and those found in the glands (Fig. 17). Positive expression of ghrelin receptor GHS-R1 is also observed in the small intestine of one-day-old rats. Fine brown granulation in the basal part of the epithelial cells of small intestine villi is present (Fig. 18)

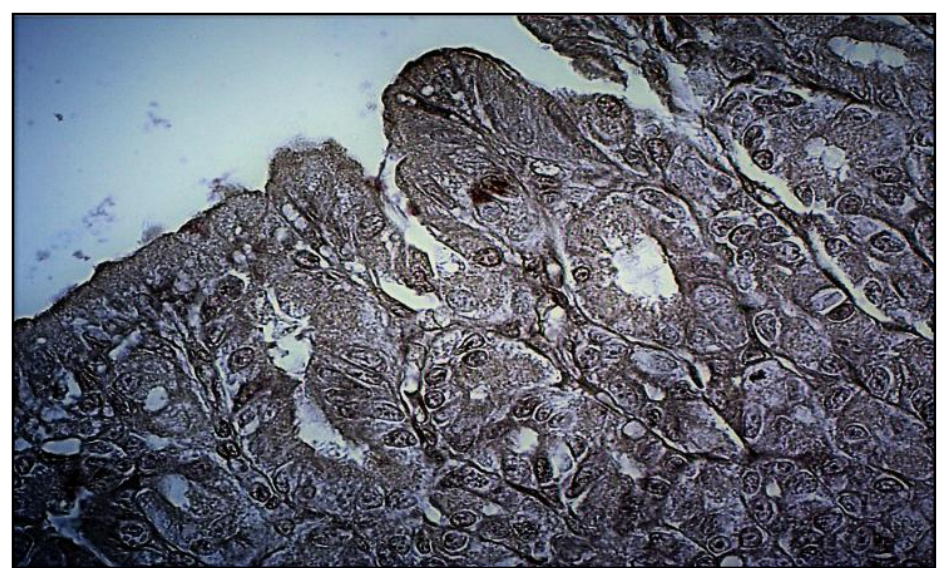

Fig. 16. Stomach of a one-day-old rat. Positive expression of GHS-R 1 in single cells from the covering epithelium of the gastric mucosa. ICH. x 40.

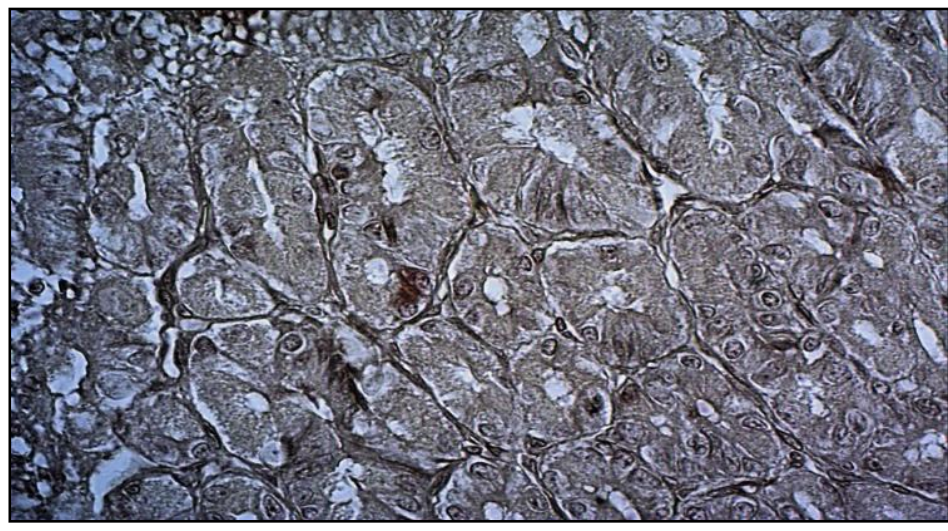

Fig. 17. Stomach of a one-day-old rat. Positive expression of GHS-R1 in single cells from the glands of the gastric mucosa. x 40 . 


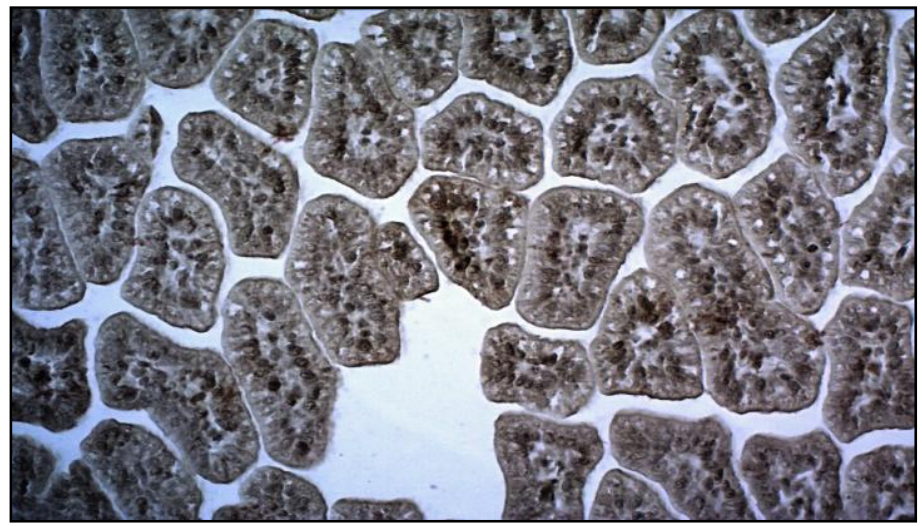

Fig. 18. Small intestine villi of one-day-old rat-cross section. Positive expression of GHS-R1 in the basal part of epithelial cells. IHC. Paraffin preparation. x 40

\section{Discussion}

Differentiation of the gastro-intestinal tract The epithelium of the primary intestine develops from embryonic endoderm which is initially formed by a line of cuboidal cells. Following induction and molecular modeling the endoderm undergoes folding in which the embryonic primary intestine forms. Although the process of endodermic tubulogenesis is still not thoroughly investigated, it is considered to include interaction with the mesenchyme which surrounds it [8]. The process is initiated by invagination in the anterior and posterior end of the embryo called anterior intestinal portal (AIP) and caudal intestinal portal (CIP). While these portals become more profound, the endoderm in the middle region is invaginated in a ventral direction in order to form the middle part of the primary intestine. With this endodermal tubulogenesis ends. In mice this process ends on $9^{\text {th }}$ gestation day $[9,10]$. In a rat $9^{\text {th }}$ gestation day an intestinal tube of single layered epithelium is formed [42]. In the period 9,5 to 13,5 gestation day the primary intestine in rat is elongated and increases in diameter due to the growth of epithelium, mesenchyme and lumen. $[42,43,44]$.

In our study we ascertain that in rat embryos endodermal tubulogenesis is complete till $8^{\text {th }}$ gestation day. In this period we observe the already formed primary intestine. Our results report that in the period $8^{\text {th }}-11^{\text {th }}$ gestation day the endoderm which forms the primary intestine seemingly begins to stratify. After it has been fully formed, the simple endodermal epithelium transforms into seemingly stratified epitheliumThis tubular structure is located in a wide, well-defined layer of mesenchyme.

According to data in scientific literature, till mid-gestation the endoderm of the oesophageal tube in most vertebrates preserves the characteristic of seemingly multilayered, multi-row epithelium [45]. Meanwhile the mesenchyme surrounding the endodermal tube thickens. Mesenchymal cells are concentrated in groups underneath the epithelium and grow in the direction of the lumen. Thus emerging villi, which are covered by cylindrical epithelial cells, are formed. The cells, as well as the mechanisms, which initiate and control epithelial reorganization and morphogenesis of villi are not thoroughly studied although the interaction between the intestinal epithelium and mesenchyme has been proven [46]. Signal pathways participating in the endodermalmesenchymal interaction include BMP, Hedgehog, PDGF, TGF- $\beta$, and Wnt pathways [46,47]. Through Hedgehog and PDGF signaling the intestinal endoderm influences the surrounding mesenchyme and regulates the differentiation of mesenchymal, myo-fibroblasts in smooth muscle cells $[47,48,49]$. Similarly to these authors, we also observed organization of mesenchymal cells under the endoblastic epithelium. They form a wide light layer of cells which is easily differentiated from the surrounding mesenchyme.

In our study the next period of $12^{\text {th }}-15^{\text {th }}$ gestation day of rat embryos the endodermal epithelium is still seemingly multilayered, multi-row. However, there is presence of myoblasts in the mesenchyme. They are in the process of layered organisation. Tufts with longitudinal and circular direction are observed. Our study of the gastrointestinal wall of rat fetuses $16^{\text {th }}$ gestation day already shows presence of sectoral differentiation. Oesophagus, stomach, small and large intestine are differentiated. However, organogenesis is still not complete. Rat fetus stomach still lacks differentiated parts- entrance, cardia; body, corpus; pylorus, pars pylorica. The gastric wall is lined with a thick layer of multi-row epithelium. Between the epithelial cells parietal areas, which mark the course of the future gastric glands, are observed. Beneath the epithelium fully formed mesenchyme, which is well vascularised but still lacks fully formed musoca with differentiated tissue layers, is found. The muscle sheath tunica muscularis is thin. Smooth muscle cells in this stage have formed two layers with different direction. In the small intestine of rat fetuses folds of covering epithelium, which begin to form villi, are observed. The folds are short and wide. They are covered with double-row and multirow epithelium. The formation of small intestine crypts also begins. At this stage they are shallow invaginations of the endoblastic epithelium towards the underlying mesenchyme in the intervillous space. 
According to Noah et al., 2011 the crypts of Lieberkühn, which contain all stem and proliferation cells of the mature intestine, are formed by the intervillous epithelium [8]. The movements of the mesenchymal cells, and not the migration of endodermic cells, play a leading role in this process [50]. Wnt, as well as BMP signal pathways are involved in crypt formation. The disturbances in signaling through these growth factors lead to the formation of abnormal crypts, which are perpendicular to the crypt-villous axis [51,52].

It has been proven that in mice the development of GIT continues in the postnatal period and is completed till the moment of weaning [8]. We ascertain that in one-day-old rats the morphogenetic and formation processes in GIT are significantly advanced. The stomach of newborn rats lack structural differences with that of adult animals. The small intestine wall has characteristics similar to that in adult animals but is significantly thinner. Villi are tall, parallel, at a certain distance from one another with thinned basal and widened central part. The cells of the covering epithelium are tall, cylindrical with well-defined striated surface - a sign for the presence of microvilli. Between the villi there are shallow, numerous crypts. The muscle sheath is formed by fusiform smooth muscle cells arranged in thick layers of different direction. Smooth muscle cells of tunica muscularis of newborn rats are completely differentiated.

Ghrelin producing cells and ghrelin receptor GHSR-1 in the developing gastro-intestinal tract The results from our immunohistochemical study of the rat's developing GIT ascertained a presence of positive expression of ghrelin and ghrelin receptor GHS-R1 during the embryonic, fetal and early postnatal period. The earliest presence of differentiated ghrelin-producing cells we found in rat embryos on $12^{\text {th }}$ gestation day. They are single cells dispersed among the endodermal epithelial cells of the esophageal tube. According to scientific literature the earliest occurrence of ghrelin-producing cells in rat is reported in fetal stomach on $18^{\text {th }}$ gestation day [32,33,34] Hayashida et al., 2002; [33] Liu et al., 2002; [34] Chanoine et al., 2004). Hayashida et al. (2002) found immunohistohchemical single ghrelin-producing cells on $18^{\text {th }}$ gestation day in the gastric mucosa of rat fetuses [33].

Our results show that in rat fetuses $16^{\text {th }}$ gestation day ghrelin-producing cells are already localized in the stomach as well as in the small intestine. The number of cells is higher in comparison to $12^{\text {th }}$ gestation day but there are single cells as well among the other epithelial cells in the midline and surface areas of the seemingly multilayered epithelium. We ascertain presence of positive ghrelin expression in one-day-old rats in the stomach and small intestine. In the stomach cardia ghrelin-producing cells are in small number localized singularly in the base of the glands. In the area of the corpus, ghrelin-producing cells are numerous, located in the corpus and base of the glands.

Hayashida et al., (2002) found presence of ghrelin-producing cells in newborn rats in which the number of positive cells is higher in comparison to their number in fetuses. Gradually this number increases. The localization of these cells is in the neck and base of stomach glands. Microscopically, ghrelin-producing cells have rounded shape and dense granules in the cytoplasm which, according to the authors, shows that their formation has begun in the late fetal stage [32]. We also observed rounded in shape ghrelin-producing cells which contain black granules in their cytoplasm.

However, some authors do not ascertain presence of positive ghrelin expression in gastric cells of rat fetuses although they found high plasma levels of ghrelin in the fetus [53,54]. Nakahara et al., (2006) explain this fact with the high permeability of the hemoplacental barrier for ghrelin, i.e. the hormone enters the fetal blood through the mother [55].

As far as the source of fetal ghrelin is concerned, according to some authors, it still remains uncertain. According to numerous studies, in this period ghrelin is produced mainly in the fetal pancreas [34,56,57]. Other authors do not ascertain such production in the foetal pancreas [58]. Chanoine (2005) presume that, in the fetal period, ghrelin is produced in the pancreas and is related to $\beta$-cell maturation in the pancreas and in addition, participates in the programming of energy balance mechanisms, anorexigenic pathways and adipogenesis [59]. Granata et al., (2010) [60] found that ghrelin activates cellular proliferation and regeneration of $\beta$-cells in the pancreas of Streptozotocin treated neonatal rats through receptor-mediated process [60].

Hayashida et al., (2002) ascertain that in the postnatal period of rat the level of plasma ghrelin increases, especially in the second and third week postpartum [32]. This happens at the expense of personal production of the stomach mucosa. Sakata et al., (2002), while studying ghrelin production in rat from $1^{\text {st }}$ to $8^{\text {th }}$ week of the postnatal period and in adult rats, ascertain that initially ghrelin-producing cells occur in the base of the chief glands of the stomach. Around $3^{\text {rd }}$ week their number increases and they spread to the corpus and neck of the glands. Authors also found sexual dimorphism in ghrelin expression in rat stomach which they associate with the significant physiological functions of ghrelin [35].

In our study of the developing rat GIT, the immunihistochemical expression of ghrelin receptor GHS$\mathrm{R} 1$ is parallel with that of the hormone itself. It is observed in the same time periods. For the first time, positive GHS-R1 positive cells are found on $12^{\text {th }}$ gestation day. These are the first results for presence of positive expression of ghrelin receptor in the earliest embryonic period of rat. In the embryonic period the receptor expression is in single endobalstic cells. In rat fetuses $16^{\text {th }}$ gestation day, expression of ghrelin receptor GHS-R1 
is found in the gastric epithelium, as well as in the smooth muscle cells of its wall. In one-day-old rats cells with positive expression of GHS-R1 are observed both in epithelial cells from the gastric mucus and in the small intestine mucus.

In literature, the presence of ghrelin receptor GHS-R in the prenatal period of rat is found as early as $20^{\text {th }}$ day gestation namely in the pancreas. Wierup et al., (2004) study the expression of ghrelin and ghrelin receptor GHS-R in islets of Langerhans of fetal and neonatal pancreas of rat. Through IHC methods the authors ascertain ghrelin-producing cells in the pancreas. By means of the methods of in situ hybridization they prove the presence of ghrelin receptor in the islet cells of rat fetuses $20^{\text {th }}$ gestation day. It is through these receptors that ghrelin exerts a paracrine effect directly on $\beta$-cells [57]. Kitazawa et al. (2011) present presence of gherlin receptor GHS-R1in GIT of rat and guinea pig through which gastro-intestinal motility is influenced [41]. Studying the disorders of the gastro-intestinal motility in rat with chronic renal insufficiency, Fu et al., (2011) ascertain IHC expression of ghrelin and ghrelin receptor GHS-R in stomach fundus and duodenum [40].

\section{Conclusion}

Ghrelin-producing cells in the gastrointestinal tract of rat embryos are differentiated early - on $12^{\text {th }}$ gestation day. In the $16^{\text {th }}$ gestation day there are differentiated ghrelin producing cells into endodermal epithelium not only in the stomach but in the small intestine. The presence of ghrelin receptors in the endoderm and myoblast of the developing esophageal tube during the embryonic and fetal period presumes the participation of ghrelin as and inductive signal in the complex processes of cellular proliferation and differentiation. The presence of receptors for ghrelin in the mucus of stomach and small intestine postpartum reveals the ability of ghrelin to participate directly in the regulation of the local processes in the gastrointestinal wall (secretion, motility, sensory function) without the mediation of the growth hormone.

\section{References}

[1]. Ovcharov, Vl., Vankov V. Human anatomy, Med. Publishing ARSO, 2012.; p.325. Sanderson I, Walker W. Development of the Gastrointestinal Tract. 1999,

[2]. http://books.google.bg/books?id=YhgKZ_dvda0C\&pg=PA174\&lpg=PA174\&dq=Larsen+W.+Development+of+the+gastrointestina $1+$ tract\&source=bl\&ots $=$ OP_uafwJvn\&sig $=$ gEvwRd-

oHX_AdHzR2pJMqu6iJok\&hl=bg\&sa=X\&ei=W7NvU5nzDuTFyQPZ_oHoBQ\&ved=0CG4Q6AEwBg\#v=onepage\&q=Larsen\%2 OW.\%20Development $\% 20$ of $\% 20$ the $\% 20$ gastrointestinal $\% 20$ tract $\& \mathrm{f}=$ false

[3]. Elsayes KM, Menias CO, Harvin HJ, Francis IR. "Imaging manifestations of Meckel's diverticulum". AJR Am J Roentgenol. 2007, 189.

[4]. Hill M. UNSW Embryology. 2014, http://php.med.unsw.edu.au/embryology/index.php?title=Gastrointestinal_Tract__Stomach_Development

[5]. Larsen W. Development of the gastrointestinal tract. In: Sherman LS, Potter SS, Scott WJ, eds. Human Embryology, 3rd ed. Philadelphia: Churchill Livingstone. 2001:235-264.

[6]. Reed RA, Womble MA, Dush MK, Tull RR, Bloom SK, Morckel AR, Devlin EW, Nascone-Yoder NM. Morphogenesis of the primitive gut tube is generated by Rho/ROCK/myosin II-mediated endoderm rearrangements. Dev Dyn. 2009;238(12):3111-25.

[7]. Roongruangchai J, Menbangphung S, Kuedpuch K, Nachaya Amonmettajit N, Pochanasomboon P, Kosol Roongruangchai K. Are there Processes of Occlusion and Recanalization in the Esophageal Development? Siriraj Med J. 2013;65(1):16-20.

[8]. Noah TK, Donahue B, Shroyer NF. Intestinal development and differentiation. Exp Cell Res. 2011 Nov 15;317(19):2702-10.

[9]. Wells JM, Melton DA. Early mouse endoderm is patterned by soluble factors from adjacent germ layers. Development. 2000;127(8):1563-72.

[10]. Lewis SL, Tam PP. Definitive endoderm of the mouse embryo: formation, cell fates, and morphogenetic function. Dev Dyn. 2006; 235:2315-2329.

[11]. Theodosiou N, Tabin C. Wnt signaling during development of the gastrointestinal tract. Dev Biol. 2003 Jul 15;259(2):258-71.

[12]. Maunoury R, Robine S, Pringault E, Huet C, Guenet Jl, Gaillard JA, Louvard D. Villin expression in the visceral endoderm and in the gut angle during early mouse embryogenesis. The EMBO Journal. 1988; 7: 3321-9.

[13]. Pinto D, Robine S, Jaisser F, Marjou FE, Louvard D. Regulatory sequences of the mouse villin gene that efficiently drive transgenic expression in immature and differentiated epithelial cells of small and large intestines. J Biol Chem. 1999;274(10):647682.

[14]. Roberts DJ, Johnson RL, Burke AC, Nelson CE, Morgan BA, Tabin C. Sonic hedgehog is an endodermal signal inducing Bmp-4 and Hox genes during induction and regionalization of the chick hindgut. Development. 1995;121:3163-3174.

[15]. Litingtung Y, Lei L, Westphal H, Chiang C. (1998) Sonic hedgehog is essential to foregut development. Nat Genet.;20:58-61.

[16]. Wodarz A, Nusse R. Mechanisms of Wnt signaling in development. Annu Rev Cell Dev Biol. 1998;14:59-88.

[17]. Lickert H, Kispert A, Kutsch S, Kemler R. Expression patterns of Wnt genes in mouse gut development. Mech Dev. 2001;105:181184.

[18]. Faure S, de Santa Barbara P, Roberts DJ, Whitman M. Endogenous patterns of BMP signaling during early chick development. Dev Biol. 2002;244:44-65.

[19]. Trhair J, Robinson P. (1989) The development of the ovine small intestine. Anat. Rec.;214:294 - 303.Tschöp M, Smiley DL, Heiman ML. Ghrelin induces adiposity in rodents. Nature. 2000;407:908-13.

[20]. Vachon PH, Cardin E, Harnois C, Reed JC, Vézina A. Early establishment of epithelial apoptosis in the developing human small intestine. Int. J. Dev.Biol. 2000;44:891-898.

[21]. Batlle E, Henderson JT, Beghtel H, van den Born MM, Sancho E, Huls G, Meeldijk J, Robertson J, van de Wetering M, Pawson T, Clevers H. Beta-catenin and TCF mediate cell positioning in the intestinal epithelium by controlling the expression of EphB/ephrinB. Cell. 2002 Oct 18;111(2):251-63.

[22]. Kim BM, Buchner G, Miletich I, Sharpe PT, Shivdasani RA. The stomach mesenchymal transcription factor Barx1 specifies gastric epithelial identity through inhibition of transient Wnt signaling. Dev Cell. 2005;8(4):611-22. 
[23]. Raghoebir L, Bakker ER, Mills JC, Swagemakers S, Kempen MB, Munck AB, Driegen S, Meijer D, Grosveld F, Tibboel D, Smits R, Rottier RJ. SOX2 redirects the developmental fate of the intestinal epithelium toward a premature gastric phenotype. J Mol Cell Biol. 2012;4(6):377-85.

[24]. Kojima A, Hosoda H, Date Y, Nakazato M, Matsuo H, Kangawa K. Ghrelin is a growth-hormone-releasing acylated peptide from stomach. Nature. 1999;402:656-660.

[25]. Salzet M., R. Day, Endocrine markers of cellular immunity: defining the endocrine phenotype. J. Soc. Biol. 2003;197(2):97-101.

[26]. Tschöp M, Smiley DL, Heiman ML. Ghrelin induces adiposity in rodents. Nature. 2000;407:908-13.

[27]. Asakawa A, Inui A, Kaga T, Yuzuriha H, Nagata T, Uen N, Makino S, Fujimiya M, Niijima A, Fujino M, Kasuga M. Ghrelin is an appetite-stimulatory signal from stomach with structural resemblance to motilin. Gastroenterology. 2001;120(2):337-345.

[28]. Toshinai K, Mondal MS, Nakazato M, Date Y, Murakami N, Kojima M, Kangawa K, Matsukura S. Upregulation of Ghrelin expression in the stomach upon fasting, insulin-induced hypoglycemia, and leptin administration. Biochem Biophys Res Commun. 2001;281(5):1220-5.

[29]. Dornonville de la Cour C, Bjorkqvist M, Sandvik A, Bakke I, Zhao C, Chen D, Hakanson R. A-like cells in the rat stomach contain ghrelin and do not operate under gastrin control. Regulatory Peptides. 2001;99:141-150.

[30]. Lee HM, Wang G, Englander EW, Kojima M, Greeley GH Jr. Ghrelin, a new gastrointestinal endocrine peptide that stimulates insulin secretion: enteric distribution, ontogeny, influence of endocrine, and dietary manipulations, Endocrinology. 2002;143,185190.

[31]. Martin-Pastor M., De Capua A, Alvarez C, Diaz-Hernandez M, J.Jimenez-Barbero, F. F. Casanueva, Y. Pazos. Interaction between ghrelin and the ghrelin receptor (GHS-R1a), a NMR study using living cells. Bioorg Med Chem. 2010;18(4):1583-1590.

[32]. Hayashida T, Nakahara K, Mondal1 M, Date Y, NakazatoM, Kojima M, Kangawa K, Murakami N. Ghrelin in neonatal rats: distribution in stomach and its possible role. Journal of Endocrinology. 2002;173:239-245.

[33]. Liu YL, Yakar S, Otero-Corchon V, Low MJ, Liu JL. Ghrelin gene expression is age-dependent and the level of circulating IGF-1. Mol Cell Endocrinol. 2002;189:97-103.

[34]. Chanoine JP, Wong AC. Ghrelin gene expression is markedly higher in fetal pancreas compared with fetal stomach: effect of maternal fasting. Endocrinology. 2004;145(8):3813-20.

[35]. Sakata I, Tanaka T, Matsubara M, Yamazaki M, Tani S, Hayashi Y, Kangawa K, Sakai T. Postnatal changes in ghrelin mRNA expression and in ghrelin-producing cells in the rat stomach. Journal of Endocrinology. 2002;174(3):463-471.

[36]. Howard A, Feighner S., Cully D, Arena J, Liberator P, Rosenblum, C, Hamelin M, Hreniuk D, Palyha O, Anderson J, Paress P, Diaz C, Chou M, Liu K, McKee K, Pong S, Chaung L, Elbrecht A, Dashkevicz M, Heavens R, Rigby M, Sirinathsinghji Dean D, Melillo D, Patchett A, Nargund R, Griffin PR, DeMartino Gupta S, Schaeffer J, Smith R, Van der Ploeg L. A receptor in pituitary and hypothalamus that functions in growth hormone release. Science. 1996;273:974-977.

[37]. Moreno M, Chaves JF, Sancho-Bru P, Ramalho F, Ramalho LN, Mansego ML, Ivorra C, Dominguez M, Conde L, Millán C, Marí M, Colmenero J, Lozano JJ, Jares P, Vidal J, Forns X, Arroyo V, Caballería J, Ginès P, Bataller R. Ghrelin attenuates hepatocellular injury and liver fibrogenesis in rodents and influences fibrosis progression in humans. Hepatology. 2010,51(3):974-85.

[38]. Chow KB, Sun J, Chu KM, Tai Cheung W, Cheng CH, Wise H. The truncated ghrelin receptor polypeptide (GHS-R1b) is localized in the endoplasmic reticulum where it forms heterodimers with ghrelin receptors (GHS-R1a) to attenuate their cell surface expression. Mol Cell Endocrinol. 2012;348(1):247-54.

[39]. Albarrán-Zeckler RG, Smith RG. The ghrelin receptors (GHS-R1a and GHS-R1b). Endocr Dev. 2013;25:5-15.

[40]. Fu RG, Yuan HZ, Wang L, Ge H, Zhang J, Ning QL, Zhang FJ. Expression of ghrelin and its receptor GHS-R in the hypothalamus and gastrointestinal tract in rats with chronic renal failure. Nan Fang Yi Ke Da Xue Xue Bao. 2011;31(1):96-9.

[41]. Kitazawa T, Nakamura T, Saeki A, Teraoka H, Hiraga T, Kaiya H. Molecular identification of ghrelin receptor (GHS-R1a) and its functional role in the gastrointestinal tract of the guinea-pig.Peptides. 2011;32(9):1876-86.

[42]. Sherwoodd R, Maehra R, Mazzonib E, Meltonc D. Wnt signaling specifies and patterns intestinal endoderm, Mechanisms of Development. 2011;128,(7-10):387-400.

[43]. Mathan M, Moxey PC, Trier JS. Morphogenesis of fetal rat duodenal villi. Am J Anat. 1976;146:73-92.

[44]. Madara JL, Neutra MR, Trier JS. Junctional complexes in fetal rat small intestine during morphogenesis. Dev Biol. 1981;86:170178 .

[45]. Barbara S, Van Den Brink G, Roberts D. Development and differentiation of the intestinal epithelium. Cell Mol Life Sci. 2003; 60(7): 1322-1332.

[46]. Spence JR, Lauf R, Shroyer NF. Vertebrate intestinal endoderm development. Dev Dyn. 2011;240:501-520.

[47]. McLin VA, Henning SJ, Jamrich M. The role of the visceral mesoderm in the development of the gastrointestinal tract. Gastroenterology. 2009;136:2074-2091.

[48]. Karlsson L, Lindahl P, Heath JK, Betsholtz C. Abnormal gastrointestinal development in PDGF-A and PDGFR-(alpha) deficient mice implicates a novel mesenchymal structure with putative instructive properties in villus morphogenesis. Development. 2000;127:3457-3466.

[49]. Van den Brink GR. Hedgehog signaling in development and homeostasis of the gastrointestinal tract. Physiol Rev. 2007;87:13431375 .

[50]. Calvert R, Pothier P. Migration of fetal intestinal intervillous cells in neonatal mice. Anat Rec. 1990;227:199-206.

[51]. Haramis AP, Begthel H, van den Born M, van Es J, Jonkheer S, Offerhaus GJ, Clevers H. De novo crypt formation and juvenile polyposis on BMP inhibition in mouse intestine. Science. 2004;303:1684-1686.

[52]. Madison BB, Braunstein K, Kuizon E, Portman K, Qiao XT, Gumucio DL. Epithelial hedgehog signals pattern the intestinal cryptvillus axis. Development. 2005;132:279-289.

[53]. Bancs WA, Tschop M, Robinso SM, Heiman ML. Extent and direction of ghrelin transport across the blood - brain barrier is determined by it uniqe primary structure. Regul. Pept. 2002;1007(1-3):63-9.

[54]. Chanoine J-P, De Waele K, Walia P. Ghrelin and the growth hormone secretagogue receptor in growth and development. International Journal of Obesity. 2009;33:48-52.

[55]. Nakahara K, Nakagawa M, Baba Y, Sato M, Toshinai K, Date Y, Nakazato M, Kojima M, Miyazato M, Kaiya H, Hosoda H, Kangawa K, Murakami N.. Maternal ghrelin plays an important role in rat fetal development during pregnancy. Endocrinology. 2006;147:1333-1342.

[56]. Prado CL, Pugh-Bernard AE, Elghazi L, Sosa-Pineda B, Sussel L. Ghrelin cells replace insulin-producing beta cells in two mouse models of pancreas development. Proc Natl Acad Sci U S A. 2004;101(9):2924-9.

[57]. Wierup N, Yang S, McEvilly RJ, Mulder H, Sundler F. Ghrelin is expressed in a novel endocrine cell type in developing rat islets and inhibits insulin secretion from INS-1 (832/13) cells. J Histochem Cytochem. 2004;52(3):301-10. 
[58]. Andralojc KM, Mercalli A, Nowak KW, Albarello L, Calcagno R, Luzi L, Bonifacio E, Doglioni C, Piemonti L. Ghrelin-producing epsilon cells in the developing and adult human pancreas. Diabetologia. 2009;52(3):486-93.

[59]. Chanoine JP. Ghrelin in growth and development. Horm Res. 2005;63(3):129-38.

[60]. Granata R, Baragli A, Settanni F, Scarlatti F, Ghigo E. Unraveling the role of the ghrelin gene peptides in the endocrine pancreas. J Mol Endocrinol. 2010;45(3):107-18. 